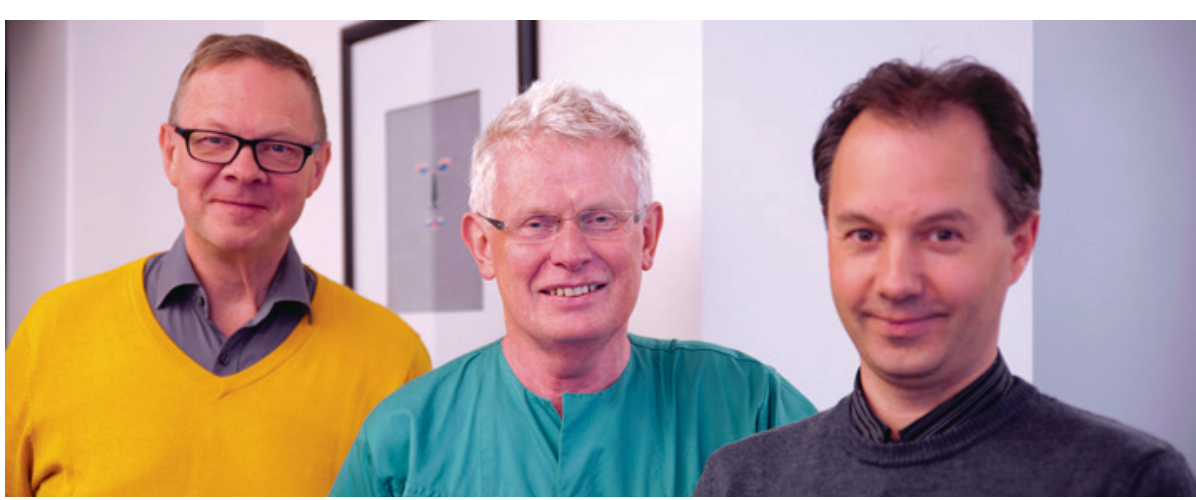

Fra venstre: Stig Harthug, Eirik Søfteland, Arvid Haugen. Foto: Aleksander Valestrand, Kommunikasjonsavdelingen, Helse Bergen

\section{Sjekklister gir færre komplikasjoner}

Verdens helseorganisasjons sjekkliste for trygg kirurgi reduserer antall komplikasjoner og forkorter liggetiden etter operasjon, viser ny norsk studie.

Mange kirurgiske komplikasjoner og dødsfall kunne vært forebygget. I 2008 lanserte Verdens helseorganisasjon (WHO) en sjekkliste til bruk før operasjonsstart, utviklet for å forebygge komplikasjoner og uønskede hendelser. En norsk forskergruppe har nylig publisert en studie der de undersøker effekten av sjekklisten i en trinnvis klyngerandomisert, kontrollert studie (1).

En sjekkliste tilpasset norske forhold ble sekvensielt implementert i fem operasjonsenheter i Helse Førde og Helse Bergen over ti måneder i 2009-10. Alle pasientene som ble operert, ble fulgt i hele perioden. Enheter der sjekklisten ennå ikke var innført, fungerte som kontrollgruppe. Sjekklisten ble introdusert for operasjonsteamene i form av videopresentasjoner, korte undervisnings $ø$ kter og trening i praktisk gjennomføring. Totalt 2212 inngrep før innføring ble sammenliknet med 2263 inngrep etter innføring av sjekklisten.

Forekomsten av komplikasjoner var lavere i sjekklistegruppen $(11,5 \%)$ enn i kontrollgruppen $(19,9 \%, \mathrm{p}<0,0001)$, dvs. en absolutt risikoreduksjon på $8,4(95 \% \mathrm{KI}$ 6,3-10,5). Effekten holdt seg etter justering for mulige konfunderende faktorer. Gjennomsnittlig liggetid var 0,8 dager lavere etter innføring av sjekklisten (95\% KI $0,11-1,43)$. Død under sykehusopphold ble redusert fra $1,9 \%$ til $0,2 \%$ i ett av de to sykehusene, men den samlede reduksjonen totalt var ikke signifikant. Etterlevelsen av sjekklistebruk var $73,4 \%$.

- Tidligere studier har vist at innføring av sjekklisten gir lavere forekomst av komplikasjoner og perioperativ mortalitet, men er blitt kritisert for metodesvakheter (2). Vi har derfor valgt en annen metodisk tilnærming, sier Stig Harthug, som er artikkelens sisteforfatter.

- Det er utfordrende å gjennomføre gode forskningsprosjekter om klinisk kvalitetsforbedring. En vesentlig grunn til at vi har lyktes, er at vi jobbet tverrfaglig og med en forskningsgruppe med den nødvendige kompetansen, sier han.

- Studien ble omtalt på lederplass i Annals of Surgery og fikk ros for sterk metodisk tilnærming, og fordi implementeringsprosessen er grundig dokumentert i studien, sier Harthug.

\section{Forskning om klinisk \\ kvalitetsforbedring}

Denne studien inngikk i ph.d.-avhandlingen til Arvid Haugen, som disputerte ved Universitetet i Bergen i august 2014. Forskningsprosjektet springer ut fra sjekklisteforskningsmiljøet ved Kirurgisk serviceklinikk i Helse Bergen, der Eirik Søfteland og Stig Harthug fra Forsknings- og utviklingsavdelingen i Helse Bergen og Monica Wammen Nordtveit ved Høgskolen i Bergen har vært sentrale. Prosjektleder har vært Barthold Vonen fra Universitet i Tromsø Norges arktiske universitet. Dessuten har pasientsikkerhetsforskere ved Imperial College i London deltatt. Tre andre ph.d.-prosjekter om sjekklistebruk og implementeringsarbeid $\mathrm{i}$ klinisk praksis pågår nå.

\section{Lise Mørkved Helsingen}

Tidsskriftet

\section{Litteratur}

1. Haugen AS, Søfteland E, Almeland SK et al. Effect of the world health organization checklist on patient outcomes: a stepped wedge cluster randomized controlled trial. Ann Surg 2015: 261.821-8.

2. Haynes AB, Weiser TG, Berry WR et al; Safe Surgery Saves Lives Study Group. A surgical safety checklist to reduce morbidity and mortality in a global population. N Engl J Med 2009; 360: 491-9.

Publisert først på nett.
Ordforklaringer

Klyngerandomisert, kontrollert studie [«stepped wedge cluster randomized controlled trial»): Studiedesignen kan beskrives som en stegvis innføring av en intervensjon, hvor rekkefølgen for implementeringen på individ- eller gruppenivå er tilfeldig. Intervensjonen implementeres for én gruppe om gangen, inntil alle gruppene har mottatt intervensjonen. Når intervensjonen er innført som rutine, blir den kontinuert. Designen er velegnet for pasientsikkerhetsintervensjoner hvor det er grunn til å anta at intervensjonen vil gjøre mer nytte enn skade.

Kirurgisk sjekkliste: En formalisert liste med punkter eller elementer som skal verifiseres som gjennomgått. Punktene skal hver for seg sikre at man har utført prosedyrer som er dokumentert å ha betydning for behandling og resultat. Sjekklisten er ikke en prosedyre i seg selv, men en kontroll av at viktige prosedyrer er utført.

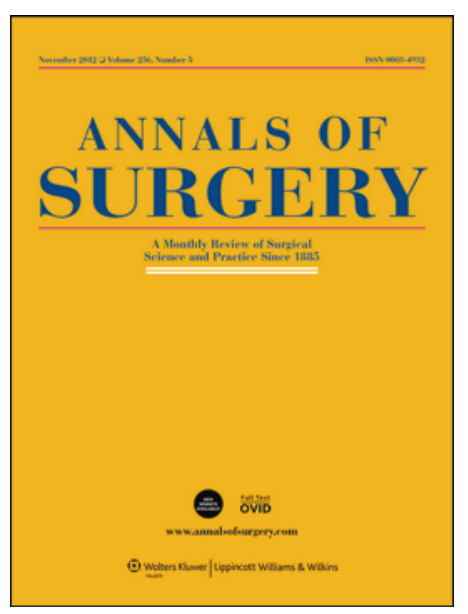

Studien ble publisert i Annals of Surgery i mai 2015 